\title{
Serial Studies on the Metabolism of Human Adipose Tissue. II. Effects of Caloric Restriction and Refeeding on Lipogenesis, and the Uptake and Release of Free Fatty Acids in Obese and Nonobese Individuals *
}

\author{
R. B. Goldrick $\dagger$ ANd Jules Hirsch \\ - \\ (From the Rockefeller Institute, New York, N. Y.)
}

The effects of changes in caloric balance on the metabolism of adipose tissue have been studied extensively in the rat. During starvation, the release of free fatty acids (FFA) from adipose tissue is enhanced, and FFA uptake as well as lipogenesis from glucose and acetate is depressed (1-6). On refeeding, the metabolic functions of this tissue rapidly revert toward normal (5-7). There have been no systematic studies of this kind in man, largely because of the difficulty in obtaining samples of adipose tissue for serial estimations of metabolic activity.

In an accompanying communication (8), a technique is described that permits serial studies of the rates of glucose and acetate lipogenesis as well as FFA uptake and release in human adipose tissue. This is achieved by the in vitro incubation of small shreds of tissue removed by needle aspiration. The present report is a description of the effects of caloric restriction and refeeding on obese and nonobese humans when studied by this method.

\section{Materials and Methods}

All subjects were carefully selected to exclude the presence of organic disease other than obesity and were admitted to a metabolic ward for the purposes of this investigation. Relevant clinical data are given in Table I. Two obese individuals, E.K. and A.G.M., were studied over long periods during which the caloric intake was varied to induce large changes in body weight. Three

* Submitted for publication January 27, 1964 ; accepted May 15, 1964.

Supported in part by U. S. Public Health Service grants HE-06222-03 and -02 from the National Heart Institute.

† In receipt of an Overseas Traveling Fellowship from the National Heart Foundation of Australia. other obese persons, A.S., S.K., and S.J., were studied for shorter periods of time during the course of weight reduction. In each instance, calories, when given, were provided by liquid formula diets (9) in which the relative proportions of protein, fat (corn oil), and carbohydrate calories were constant ( $\mathrm{P}: \mathrm{F}: \mathrm{C}=15: 40: 45)$. In addition, three nonobese volunteers, C.T.B., M.O.M., and B.E.J., were observed for brief periods of constant caloric intake (isocaloric state) and also during complete starvation.

Details of the technique for aspirating samples of adipose tissue and the methods used for measuring glucose and acetate lipogenesis as well as FFA uptake and release are described in an accompanying report (8). Observations in any one individual were always made on tissues removed from the same site (either the buttock or the anterior abdominal wall). Unless otherwise specified, adipose tissue aspirations were performed at $10: 30$ a.m., i.e., $2 \frac{1}{2}$ hours after the first formula feeding of the day. The distribution of incorporated glucose- $\mathrm{C}^{14}$ between glyceride-glycerol and glyceride-fatty acids and the percentage of esterification of FFA taken up by the adipose tissue were also studied (8). Plasma FFA levels were measured by the method of Dole (10).

\section{Results}

The effects of total and partial caloric restriction on adipose tissue metabolism

a) Glucose lipogenesis. The rates of glucose lipogenesis (glucose incorporation into adipose glycerides measured in vitro) in five subjects who were first observed in a period of constant caloric intake and then starved for varying periods of time are illustrated in Figure 1. The average values for each individual are shown in Table II. In spite of marked day-to-day variations in some individuals, it is evident that in all cases caloric deprivation depressed but did not abolish glucose lipogenesis as measured by the incorporation of $\mathrm{C}^{14}$-glucose into adipose lipids. Additional data 
TABLE I

Clinical features of patients subjected to caloric restriction

\begin{tabular}{lccccl}
\hline Subject. & Age & Sex & Height & $\begin{array}{c}\text { Admission } \\
\text { weight }\end{array}$ & Diagnosis \\
\hline & & & $c m$ & $k g$ & \\
E.K. & 46 & M & 160 & 123.0 & Obesity \\
A.G.M. & 21 & F & 154 & 102.1 & Obesity \\
S.K. & 22 & F & 164 & 117.8 & Obesity \\
S.J. & 27 & F & 156 & 100.7 & Obesity \\
A.S. & 38 & M & 168 & 171.6 & Obesity \\
B.E.J. & 45 & F & 165 & 50.2 & Healthy* \\
C.T.B. & 24 & F & 164 & 54.4 & Healthy* \\
M.O.M. & 45 & F & 157 & 65.0 & Healthy* \\
& & & & & \\
\hline
\end{tabular}

* These three nonobese individuals belong to a religious sect whose members habitually practice fasting for long periods.

were obtained when the two obese subjects shown in Figure 1 were placed on a formula providing 600 calories per day. The results shown in Table II indicate that a 600-calorie diet produced changes that were similar to those recorded during starvation. The average decrease in glucose lipogenesis induced by starvation or semistarvation was $44 \%$ of the control value, the degree of depression being similar in obese and nonobese subjects.

Analysis of the distribution of glucose- $\mathrm{C}^{14}$ between adipose glyceride-glycerol and total tissue fatty acids under isocaloric conditions (subject E.K.) revealed that glucose- $\mathrm{C}^{14}$ incorporated into tissue fatty acids averaged only $16 \%$ of the total tissue lipid- $\mathrm{C}^{14}$. Under these circumstances the major portion of the glucose label from the medium is evidently found in tissue glyceride-glycerol after incubation. During starvation, however, there was no tissue fatty acid labeling; hence, in this situation, glucose- $\mathrm{C}^{14}$ was incorporated exclusively into glyceride-glycerol. Since the depression of glucose lipogenesis induced by starvation almost invariably exceeded $16 \%$, it is clear that the depression of incorporation of $\mathrm{C}^{14}$-glucose label into adipose lipid was attributable only to a minor degree to cessation of fatty acid synthesis

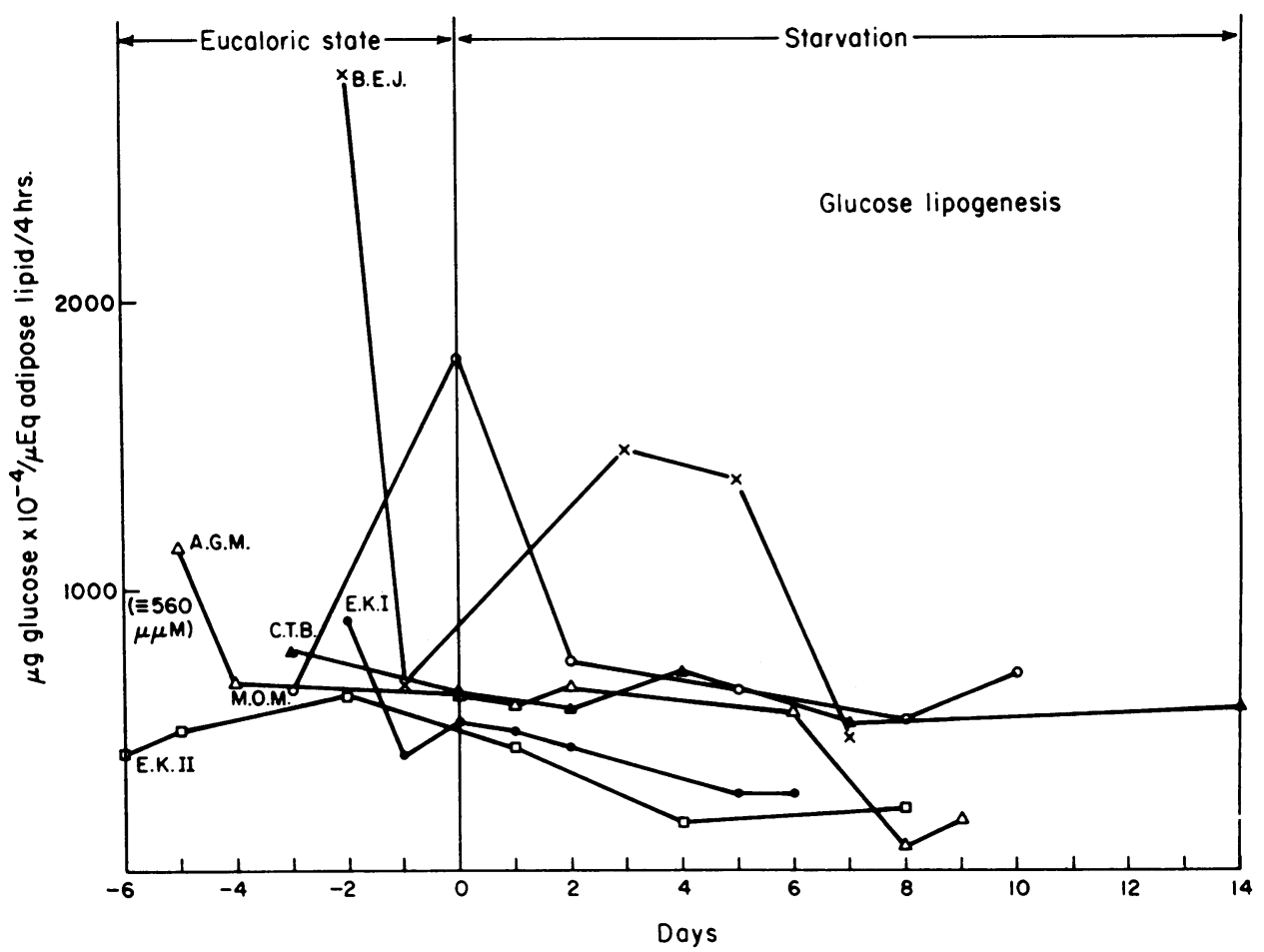

Fig. 1. THE EFFECTS OF TOTAL CALORIC DEPRIVATION ON GLUCOSE INCORPORATION INTO ADIPOSE GLYCERIDES IN TWO OBESE (A.G.M. AND E.K.) AND THREE NONOBESE INDIVIdUALS (B.E.J., C.T.B., AND M.O.M.). Each datum is calculated from the average specific radioactivity of four groups of tissue shreds removed in a single aspiration and incubated together. Eucaloric $=$ caloric intake to maintain constant body weight. 
TABLE II

The effects of total and partial caloric restriction on glucose and acetate lipogenesis, $F F A$ release, and plasma $F F A$ levels

\begin{tabular}{|c|c|c|c|c|c|}
\hline Subject & Diet & Glucose lipogenesis & Acetate lipogenesis & FFA release & Plasma FFA \\
\hline & & $\begin{array}{c}\mu g \text { glucose } \times 10^{-4} / \mu E Q \\
\text { a.dipose lipid } / 4 \mathrm{hrs}\end{array}$ & $\begin{array}{c}\mu g \text { acetate } \times 10^{-4} / \mu E Q \\
\text { adipose lipid } / 4 \mathrm{hrs}\end{array}$ & $\begin{array}{c}\mu E q F F A / m E q \\
\text { adipose lipid } / 2 \text { hrs }\end{array}$ & $\mu E q / L$ \\
\hline \multicolumn{6}{|l|}{ Nonobese } \\
\hline M.O.M. & $\begin{array}{l}\text { Isocaloric } \\
\text { Fasting }\end{array}$ & $\begin{array}{c}1,225(2)^{*} \\
658(4)\end{array}$ & $\begin{array}{r}723(2) \\
12(4)\end{array}$ & $\begin{array}{l}1.16(2) \\
5.2 \quad(3)\end{array}$ & $\begin{array}{l}1,199 \\
2,197(3)\end{array}$ \\
\hline B.E.J. & $\begin{array}{l}\text { Isocaloric } \\
\text { Fasting }\end{array}$ & $\begin{array}{l}1,728 \\
1,111\end{array}$ & $\begin{array}{r}2,407(2) \\
33(3)\end{array}$ & & \\
\hline C.T.B. & $\begin{array}{l}\text { Isocaloric } \\
\text { Fasting }\end{array}$ & $\begin{array}{l}711(2) \\
596(4)\end{array}$ & $\begin{array}{r}1,158(2) \\
11(4)\end{array}$ & $\begin{array}{l}0.99(2) \\
4.78(3)\end{array}$ & $\begin{array}{r}344(2) \\
1,683(3)\end{array}$ \\
\hline \multicolumn{6}{|l|}{ Obese } \\
\hline A.G.M. $\dagger$ & $\begin{array}{l}\text { Isocaloric } \\
\text { Fasting } \\
600 \text { calories/day }\end{array}$ & $\begin{array}{l}817(5) \\
414(5) \\
428(6)\end{array}$ & $\begin{array}{r}363(5) \\
7(5) \\
6(6)\end{array}$ & $\begin{array}{ll}0.60 & (2) \\
3.6 & (5) \\
4.0 & (4)\end{array}$ & $\begin{array}{r}320(3) \\
1,518(5) \\
989(5)\end{array}$ \\
\hline E.K.† & $\begin{array}{l}\text { Isocaloric I } \\
\text { Fasting I } \\
\text { Isocaloric II } \\
\text { Fasting II } \\
600 \text { calories/day }\end{array}$ & $\begin{array}{l}611(3) \\
369(4) \\
512(3) \\
278(3) \\
359(2)\end{array}$ & $\begin{array}{r}661(3) \\
72(4) \\
355(3) \\
28(3) \\
6(2)\end{array}$ & & \\
\hline
\end{tabular}

* All values are given as means obtained in each subject with the number of observations in parentheses. The individual values are shown in the accompanying figures.

$\dagger$ The body weights of the obese subjects before the onset of complete caloric deprivation were as follows: A.G.M., $91.8 \mathrm{~kg}$; E.K., first period of observation, $125.6 \mathrm{~kg}$; second period of observation, $122.2 \mathrm{~kg}$.

from glucose, but mainly to slower production of glyceride-glycerol.

When glucose lipogenesis was plotted along with body weight during the course of prolonged caloric manipulations (Figure 2), this parameter tended to parallel changes in body weight; thus, the impression was gained that, if weight reduction were continued for extremely long periods of time, glucose lipogenesis might cease altogether. The latter possibility was tested in A.G.M., who after preliminary observations during starvation and refeeding was maintained for 3 months on a diet providing 600 calories per day (Figure 3). During the early phases of the study, glucose lipogenesis tended to parallel the acute changes in body weight; however, during the course of prolonged caloric restriction, when 21 $\mathrm{kg}$ was lost, it failed to follow the weight curve, and low but relatively stable rates of lipogenesis were demonstrable throughout. Seemingly, therefore, a significant degree of lipogenic activity is maintained regardless of the duration of caloric restriction.

b) Acetate lipogenesis. Under isocaloric conditions, there were marked inter- and intraindividual variations in acetate lipogenesis (Table II

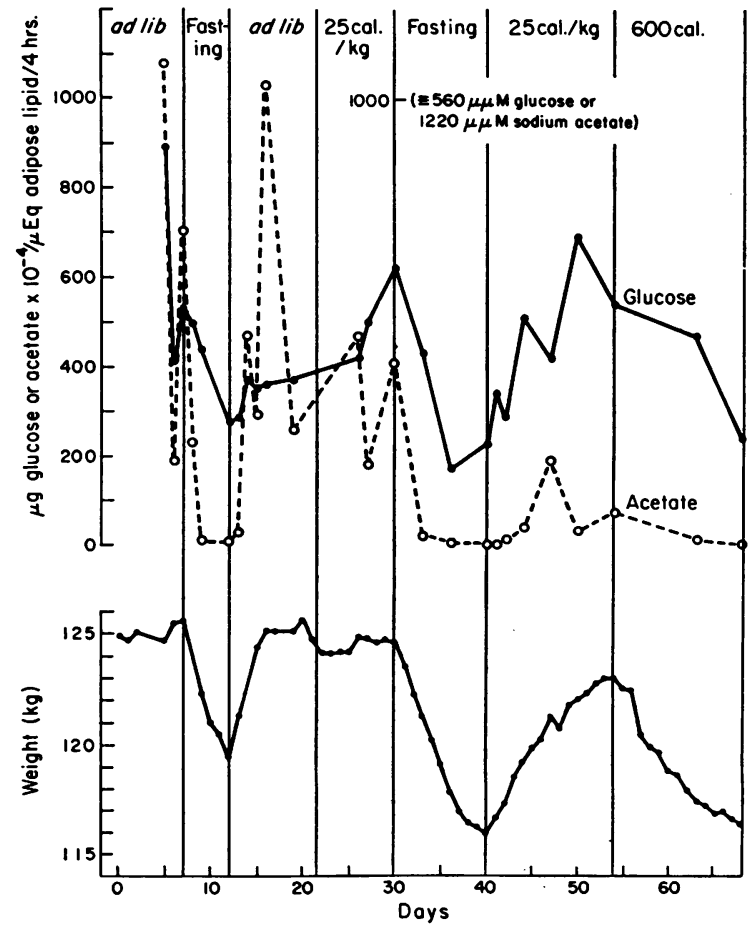

Fig. 2. Glucose and acetate lipogenesis DURING Weight CHANGeS IN E. $\mathrm{K}$. Calories, when given, were derived solely from a liquid formula diet (protein: fat: carbohydrate, $\mathrm{P}: \mathrm{F}: \mathrm{C}=15: 40: 45$ ). 


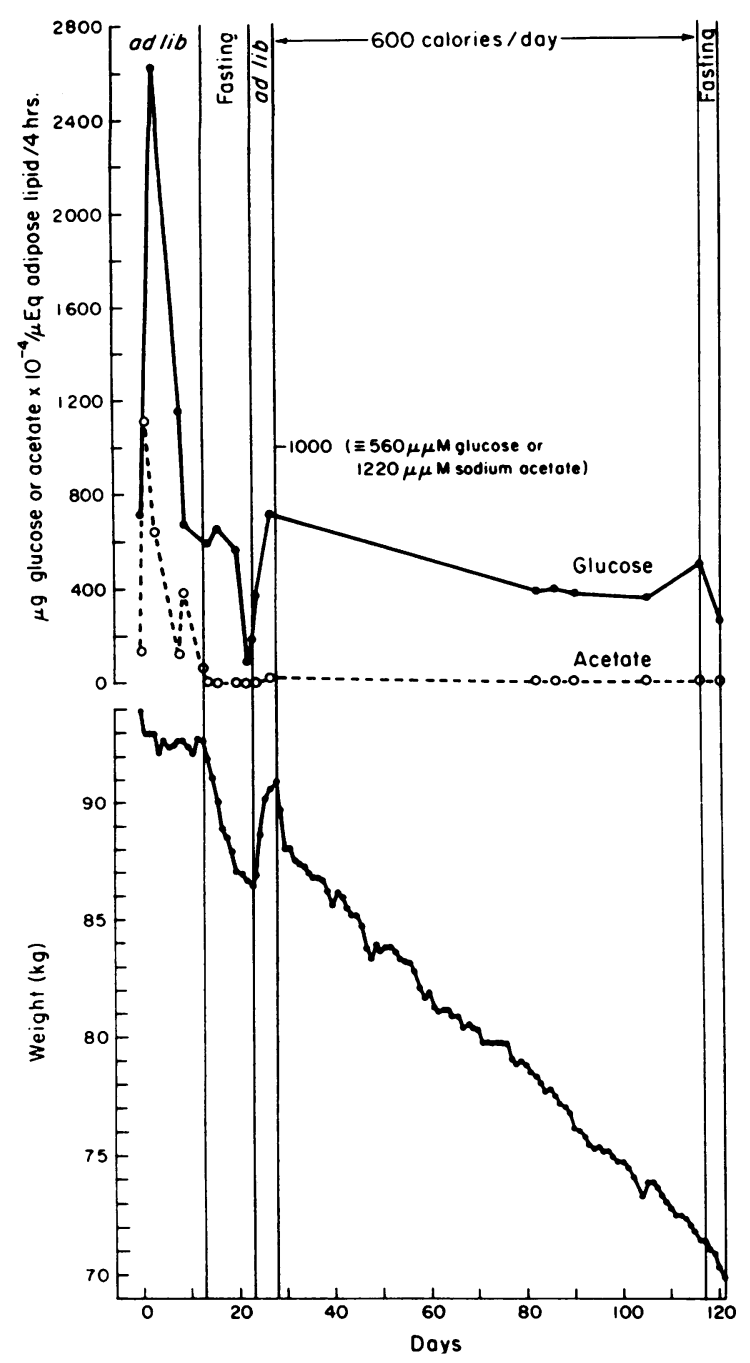

Fig. 3. Glucose AND ACEtate Lipogenesis During PROLONGED CALORIC RESTRICTION IN A.G.M. Calories, when given, were derived solely from a liquid formula $\operatorname{diet}(\mathrm{P}: \mathrm{F}: \mathrm{C}=15: 40: 45)$.

and Figure 4). An analysis of the possible causes for such variation has been given previously (8). In spite of this variation, the responses to starvation were remarkably uniform in all cases. Within 24 to 48 hours, lipogenesis fell to near zero levels and remained so throughout the period of caloric deprivation. Limitation of the caloric intake to 600 calories per day proved to be just as effective in depressing acetate lipogenesis as complete starvation (Table II). Furthermore, in contrast to glucose lipogenesis, acetate lipogenesis remained barely demonstrable even when caloric restriction was maintained for several months (Figure 3 ).
Examination of the distribution of acetate- $C^{14}$ between adipose glyceride-glycerol and glyceridefatty acids in the isocaloric state has shown that virtually all the labeling is confined to the fatty acid moiety (8). Similar data were obtained on fractionating the adipose lipids of E.K. during starvation, although under these circumstances fatty acid labeling was severely depressed. Thus, both the glucose- and acetate- $\mathrm{C}^{14}$ data indicate that de novo fatty acid synthesis was profoundly inhibited by complete caloric deprivation.

Previous studies have shown significant radioactivity in FFA in the medium after incubating adipose tissue from nonstarved individuals in bicarbonate buffer containing albumin- and acetate$\mathrm{C}^{14}$ (8). Thus, the possibility arose that during caloric restriction newly synthesized FFA was discharged into the medium rather than esterified, giving erroneously low estimates of acetate lipogenesis. However, when tissues from A.S., who had been receiving 600 calories per day for several months, were incubated under the above conditions (which permit release of newly synthesized FFA to the medium), insignificant levels of radioactivity were present in FFA in the medium. Since the method employed for separating and counting tissue lipids does not distinguish between $\mathrm{C}^{\mathbf{1 4}}$ in adipose glycerides and tissue FFA, the absence of radioactivity in adipose lipids and FFA in the medium after incubation with acetate- $\mathrm{C}^{14}$ is considered valid evidence that $d e$ novo fatty acid synthesis is severely depressed.

c) FFA release. The rates of FFA release and the plasma FFA levels in one obese and two nonobese subjects, before and during starvation, are shown in Figure 5. The average values are recorded in Table II. In all cases, an increase in the rate of FFA release accompanied the anticipated rise in plasma FFA concentration early in the starvation period. Both of these parameters underwent wide fluctuations from day to day but remained elevated above the prefasting values for as long as caloric deprivation was continued. Further inspection of Figure 5 will show that in every subject the fluctuations in plasma FFA levels closely paralleled the rates of FFA release.

d) FFA uptake and esterification. Serial measurements of fatty acid uptake and esterification were not carried out in any one individual under a variety of dietary circumstances. Ob- 


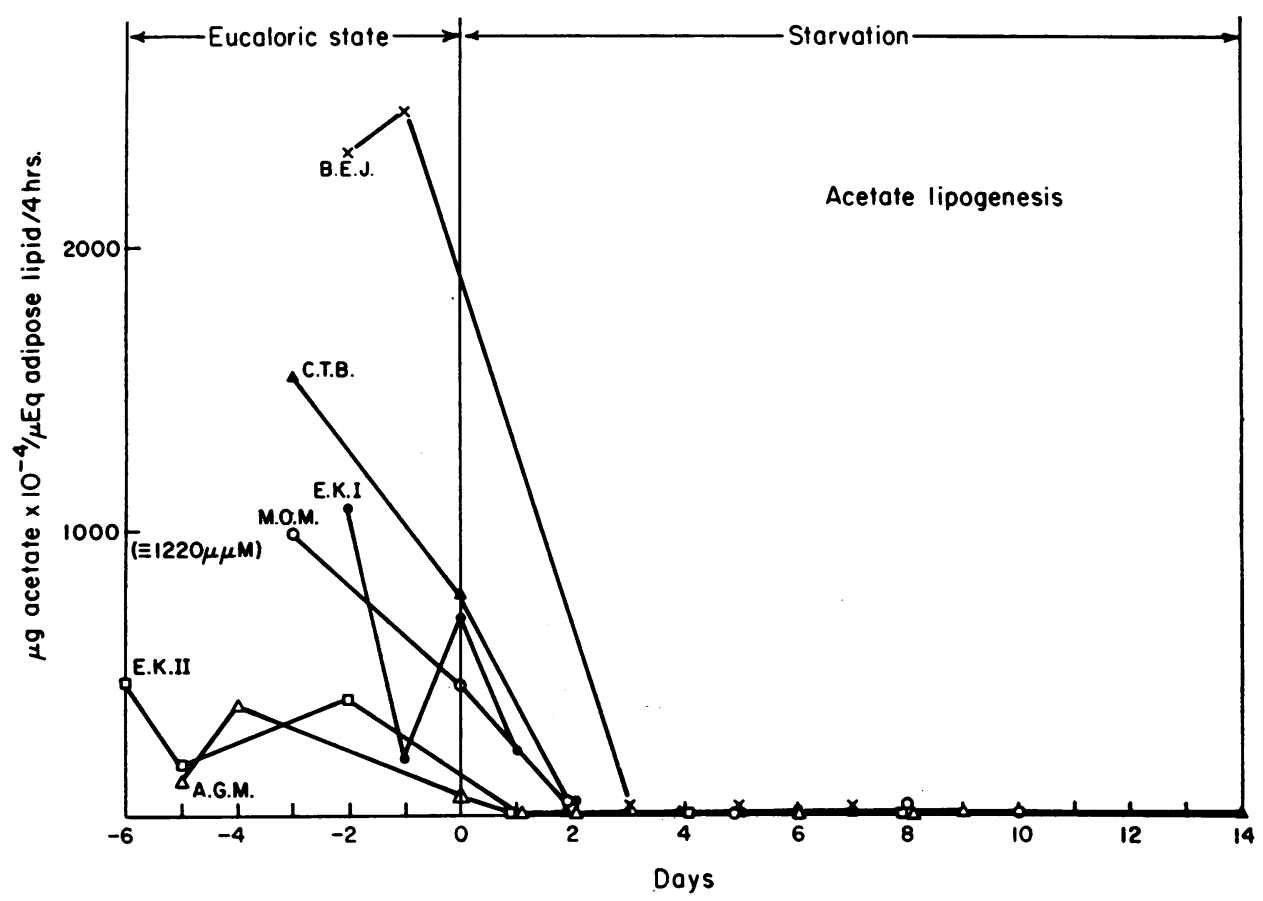

Fig. 4. THE efFects OF tOTAL CALORIC DEPRIVATION ON ACETATE inCORPORATION INTO ADIPOSE GLYCERIDES IN TWo OBESE AND THREE NONOBESE INDIviduals. See legend, Figure 1.

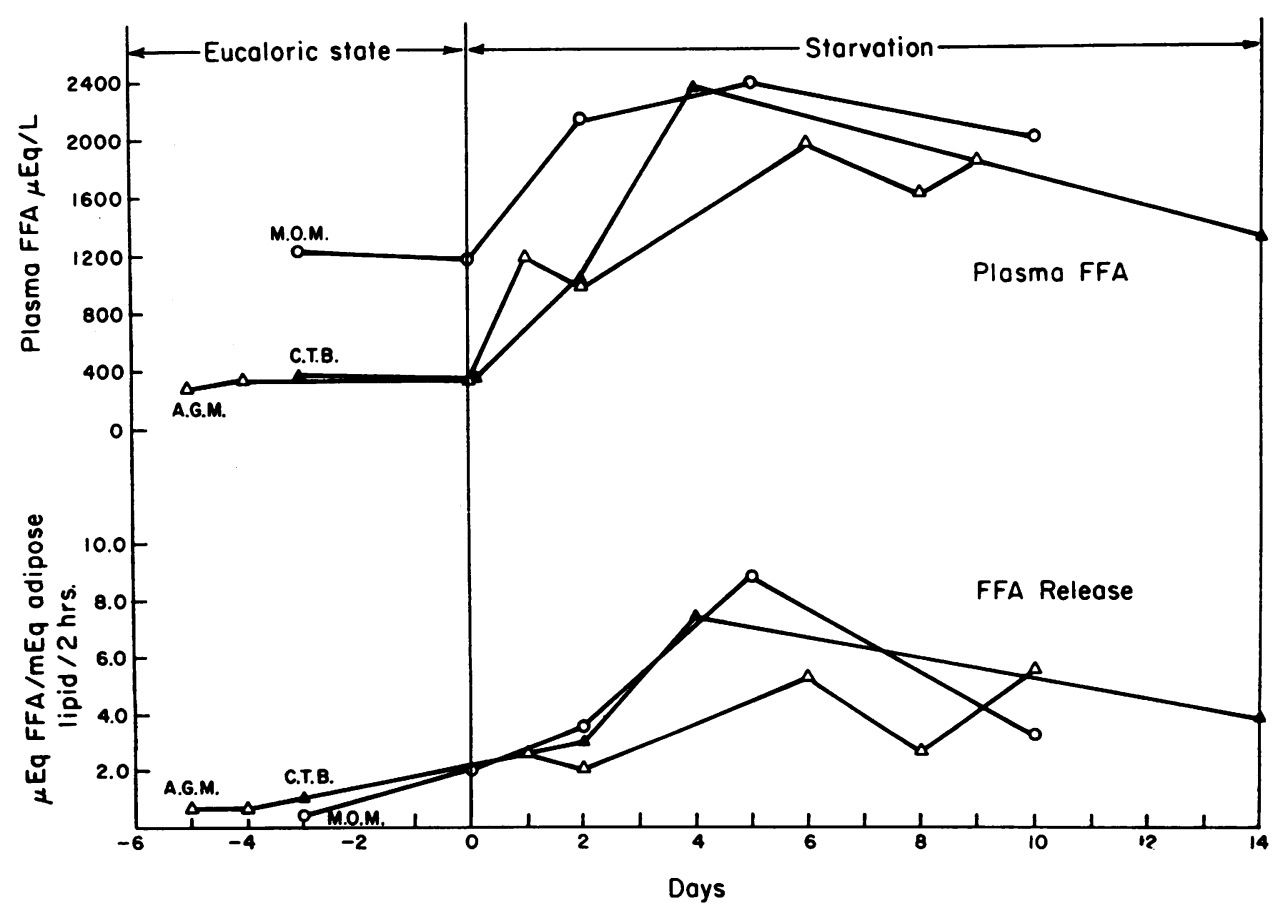

Fig. 5. THE EFFECTS OF TOTAL CALORIC DEPRIVATION ON THE RELEASE OF FFA FROM ADIPOSE TISSUE AND ON LEVELS OF PLASMA FFA IN ONE OBESE INDIVIDUAL (A.G.M.) AND TWO NONOBESE INDIVIDUALS (C.T.B. AND M.O.M.). 


\begin{tabular}{|c|c|c|c|c|c|}
\hline \multirow[b]{2}{*}{ Diet } & \multirow[b]{2}{*}{ Subjects } & \multicolumn{2}{|c|}{ FFA uptake } & \multicolumn{2}{|c|}{$\begin{array}{l}\text { Percentage of adipose- } \mathrm{C}^{14} \text { as } \\
\text { glyceride after incubation } \\
\text { with palmitic acid-C.14 }\end{array}$} \\
\hline & & $\begin{array}{l}\text { Mean } \\
\text { values for } \\
\text { individuals }\end{array}$ & $\begin{array}{l}\text { Mean values } \\
\text { for groups } \\
\text { of individuals }\end{array}$ & $\begin{array}{c}\text { Mean } \\
\text { values for } \\
\text { individuals }\end{array}$ & $\begin{array}{l}\text { Mean values } \\
\text { for groups } \\
\text { of individuals }\end{array}$ \\
\hline Isocaloric & $\begin{array}{l}\text { Nonobese individuals* } \\
\text { S.K. }\end{array}$ & $\begin{array}{l}\mu E q / \mu E q a \\
2.06(3) \dagger\end{array}$ & $\begin{array}{l}\text { lipid/2 hrs } \\
1.68(9)\end{array}$ & $\%$ & $97.7(7)$ \\
\hline 1,200 calories per day & A.G.M. & $1.33(3)$ & & $92.2(1)$ & \\
\hline 600 calories per day & $\begin{array}{l}\text { E.K. } \\
\text { S.J. } \\
\text { A.G.M. }\end{array}$ & $\begin{array}{l}0.86(3) \\
1.21(2) \\
0.56(7)\end{array}$ & $0.88(12)$ & $\begin{array}{l}98.4(1) \\
64.4(3)\end{array}$ & $81.4(4)$ \\
\hline Fasting & S.J. & $0.37(4)$ & & & \\
\hline & A.G.M. & $0.30(2)$ & $0.04(0)$ & $77.0(2)$ & \\
\hline
\end{tabular}

* Nine healthy individuals on ad libitum diets who are described in an accompanying report (8).

$\dagger$ Number of estimations given in parentheses.

servations were made, however, in a number of subjects in isocaloric and several degrees of negative caloric balance. The data are listed in Table III. Under isocaloric conditions, esterification of labeled fatty acids was close to $100 \%$, whereas

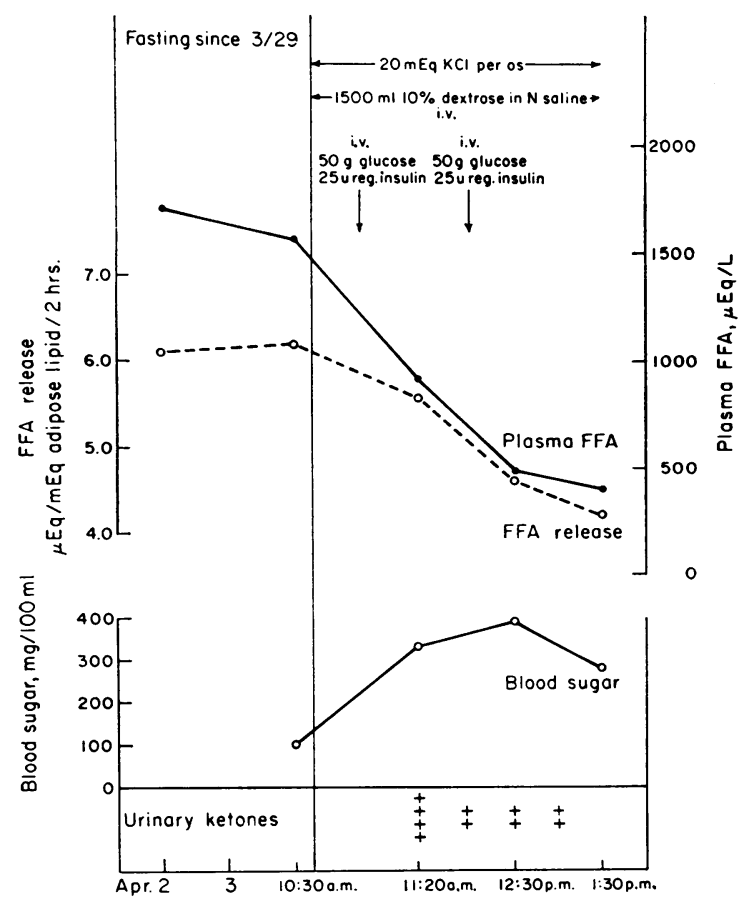

Fig. 6. Acute cessation of starvation with intraVENOUS GLUCOSE AND INSULIN. Effects on FFA release from adipose tissue and plasma FFA levels. Subject S.K.-body weight, $107.5 \mathrm{~kg}$ before this 4-day fast. in subjects in negative caloric balance an appreciable fraction of the palmitic acid- $\mathrm{C}^{14}$ was demonstrable in tissue FFA. The rate of fatty acid uptake was also consistently lower in subjects on restricted caloric intakes than in individuals in caloric balance, and the differences were such as to suggest that the rate of fatty acid uptake was inversely proportional to the severity of caloric restriction.

\section{Metabolic changes during recovery from starvation}

a) By realimentation. Serial measurements of glucose and acetate lipogenesis were carried out in two obese subjects, E.K. and A.G.M., during recovery from periods of complete starvation. Refeeding was accomplished either by allowing the subject to ingest as much liquid formula as desired (ad libitum feeding) or by regulating the intake to an equivalent of 25 calories per $\mathrm{kg}$ of body weight per day. The data are illustrated in Figures 2 and 3. Both regimens produced rapid gains in weight. However, the restoration of glucose lipogenesis towards prefasting levels was relatively slow, and the reactivation of acetate lipogenesis tended to be even more sluggish. Figure 2 contains data from two periods of starvation of 5 and 10 days duration, and in Figure 3 are the data from one 10-day period of starvation. It is interesting that acetate lipogenesis recovered rapidly only after the 5-day starvation. The longer starvations were followed by slower re- 
coveries. Supranormal levels of glucose and acetate lipogenesis were never observed during refeeding.

b) By the intravenous administration of glucose and insulin. Detailed observations were carried out in three obese individuals (S.K., E.K., and A.G.M.) over the course of several hours, during which the fasting state was abruptly terminated by the intravenous administration of glucose and insulin in sufficient quantities to decrease ketosis rapidly. The amounts of glucose were sufficient to maintain hyperglycemia throughout the period of observation; supplements of potassium chloride were given to prevent hypokalemia. The doses of glucose, insulin, and potassium chloride are shown in Figures 6 to 8 . In two of the three subjects FFA release was measured. The administration of glucose and insulin effected a prompt inhibition of FFA release and a fall in the plasma FFA levels (Figures 6 and 7). It is noteworthy that under these circumstances, as well as during starvation, both FFA release and plasma FFA concentrations changed concurrently. On the other hand, glucose and insulin administration was entirely without effect on the rates of glucose and acetate lipogenesis (Figures 7 and 8). FFA uptake by the adipose tissue showed a small but consistent increase when the fast was terminated (Figure 8). Analysis of the labeled tissue fatty acids after incubation with palmitic acid- $\mathrm{C}^{14}$ revealed an average of $77 \%$ of the total present in glycerides before and $86 \%$ after the administration of glucose and insulin. Thus, the rapid termination of the fasting state leads to an immediate change in the rate of FFA released from adipose tissue, but the other parameters measured show

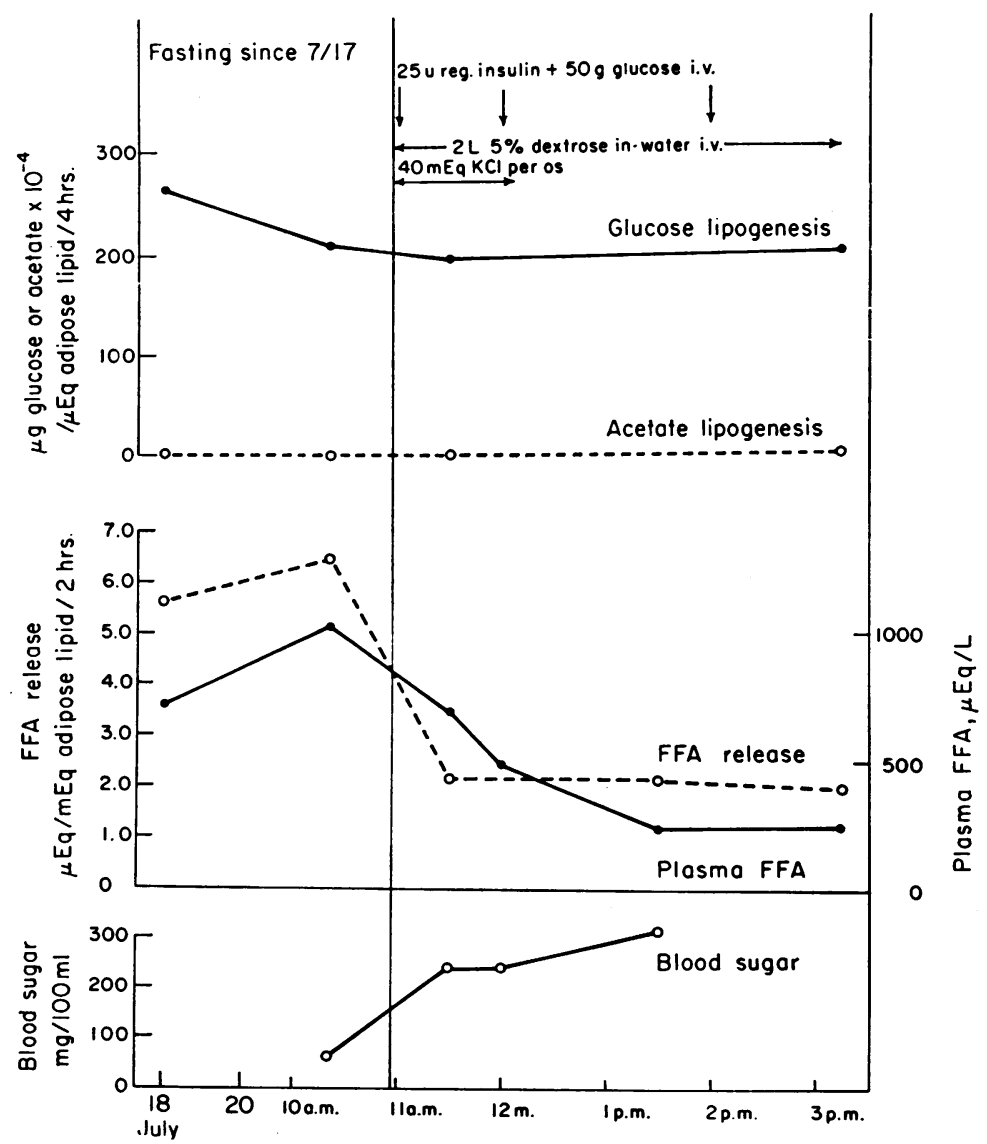

Fig. 7. Acute céssation of starvation with intravenous glucose AND InSUlin. Effects on glucose and acetate lipogenesis and FFA release. Subject E.K.-body weight, $92.1 \mathrm{~kg}$ before this 3-day fast. 


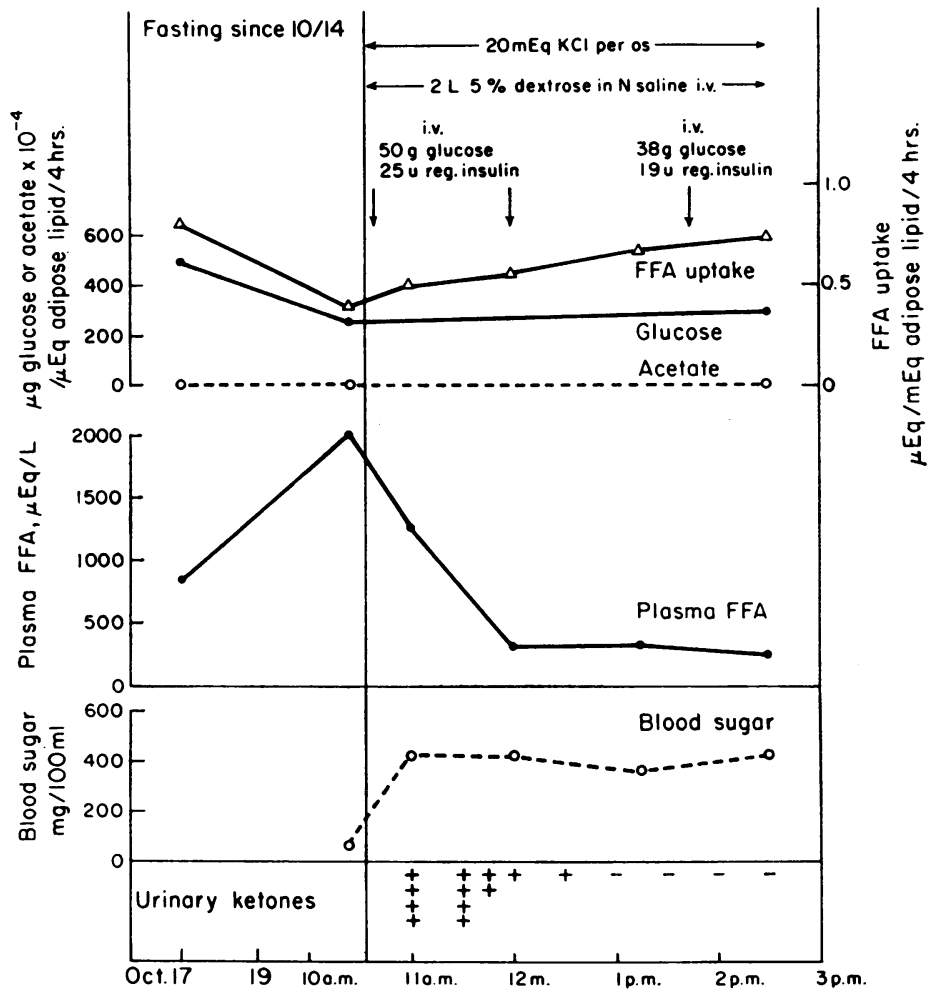

Fig. 8. Acute cessation of starvation with intravenous gluCOSE AND INSULIN. Effects on glucose and acetate lipogenesis and FFA uptake. Subject A.G.M.--body weight, $70.8 \mathrm{~kg}$ before this 5-day fast.

TABLE IV

The in vitro effects of insulin on the metabolism of adipose tissue taken from individuals receiving 600 calories per day*

\begin{tabular}{|c|c|c|c|c|c|c|c|c|}
\hline \multirow[b]{2}{*}{ Subjects } & \multirow[b]{2}{*}{ - Insulin } & \multirow[b]{2}{*}{+ Insulin $\dagger$} & \multirow[b]{2}{*}{ - Insulin } & \multirow[b]{2}{*}{ + Insulin } & \multicolumn{2}{|c|}{ FFA uptake } & \multicolumn{2}{|c|}{ FFA release } \\
\hline & & & & & -- Insulin & + Insulin & - Insulin & + Insulin \\
\hline & \multicolumn{2}{|c|}{$\begin{array}{l}\mu g \text { glucose } \times 10^{-4} / \\
\mu \text { Eq adipose lipid } / 4 \text { hrs }\end{array}$} & \multicolumn{2}{|c|}{$\begin{array}{c}\mu g \text { acetate } \times 10^{-4} / \mu E q q \\
\text { adipose lipid } / 4 \text { hrs }\end{array}$} & \multicolumn{2}{|c|}{$\begin{array}{c}\mu E q / m F q \text { adipose } \\
\text { lipid } / 2 \text { hrs }\end{array}$} & \multicolumn{2}{|c|}{$\begin{array}{c}\mu E q / m E q \text { adipose } \\
\text { lipid/2 hrs }\end{array}$} \\
\hline $\begin{array}{l}\text { S.K. } \\
\text { Exp. } 1\end{array}$ & $\begin{array}{c}259 \ddagger \\
403 \\
464 \\
(375)\end{array}$ & $\begin{array}{c}598 \\
452 \\
342 \\
(464)\end{array}$ & & & $\begin{array}{c}0.67 \\
0.73 \\
0.93 \\
(0.78)\end{array}$ & $\begin{array}{c}0.63 \\
0.79 \\
0.75 \\
(0.72)\end{array}$ & 4.00 & 4.14 \\
\hline $\begin{array}{l}\text { S.K. } \\
\text { Exp. } 2\end{array}$ & $\begin{array}{c}365 \\
738 \\
563 \\
(555)\end{array}$ & $\begin{array}{c}525 \\
527 \\
522 \\
(525)\end{array}$ & & & $\begin{array}{c}0.69 \\
1.05 \\
0.89 \\
(0.88)\end{array}$ & $\begin{array}{l}0.99 \\
0.68 \\
1.01 \\
(0.89)\end{array}$ & 3.31 & 2.56 \\
\hline A.S. & $\begin{array}{c}354 \\
475 \\
337 \\
(389)\end{array}$ & $\begin{array}{c}168 \\
143 \\
205 \\
(172)\end{array}$ & $\begin{array}{c}2.04 \\
2.33 \\
1.27 \\
1.04 \\
1.39 \\
3.13 \\
(1.87)\end{array}$ & $\begin{array}{c}1.06 \\
3.39 \\
1.58 \\
2.72 \\
2.00 \\
2.36 \\
(2.19)\end{array}$ & $\begin{array}{c}0.63 \\
0.44 \\
0.57 \\
(0.55)\end{array}$ & $\begin{array}{c}0.46 \\
0.62 \\
0.51 \\
(0.53)\end{array}$ & 4.29 & 4.93 \\
\hline
\end{tabular}

* Tissue removed from subjects A.S. and S.K. during the course of weight reduction. The body weight of A.S. was $124.9 \mathrm{~kg}$ and of S.K. $84.5 \mathrm{~kg}$ (experiment 1) and $84.1 \mathrm{~kg}$ (experiment 2).

$\dagger$ Insulin, when added to the incubation media, was present in a concentration of $0.1 \mathrm{U}$ per ml.

$\ddagger$ Replicate values from tissues removed at one aspiration. Average values are given in parentheses. 
no prompt change other than a very small enhancement of FFA uptake.

\section{In vitro study of the effects of insulin on the metabolism of starved adipose tissue.}

In view of the apparent ineffectiveness of parenterally administered insulin on glucose and acetate lipogenesis, further studies were undertaken to test the effects of this hormone on the metabolism of adipose tissue in vitro. For this purpose, tissues were removed from subjects in negative caloric balance and divided between two series of flasks containing standard incubation media. To one series of flasks was added soluble insulin in a concentration of $0.1 \mathrm{U}$ per $\mathrm{ml}$. The results are shown in Table IV. From the scatter of individual values it is clear that the effects of added insulin on glucose and acetate lipogenesis and FFA uptake were either equivocal or absent. Unfortunately, the amounts of tissue required for determining FFA release precluded replicate estimates of this parameter. Nevertheless, an unequivocal inhibition of FFA release by insulin in vitro could not be demonstrated.

On the basis of these observations, the effects of insulin on FFA release would seem to depend on the mode of presentation of this hormone to the fat cell. It is also possible, however, that the tissue concentrations of glucose and insulin derived from the incubation medium and plasma were very different. As a consequence, the discordant results may reflect differences in experimental conditions rather than some fundamental requirement for the action of insulin on adipose tissue. It is exceedingly difficult to demonstrate an insulin effect in vitro on adipose tissue removed from humans in a state of constant caloric intake (8).

\section{Discussion}

That the fat cell is an active metabolic unit performing a variety of functions of central importance in the regulation of lipid and carbohydrate metabolism is shown by the following: 1) There is continuous breakdown and resynthesis of triglycerides (11). To a large extent resynthesis is dependent upon the availability of $\alpha$-glycerophosphate with which fatty acids (as fatty acid CoA) are esterified to form di- and triglycerides (12). Consequently, the rate of incorporation of glucose label from the incubation medium into tissue glycerides can serve as an index of the rate of esterification. Glucose in the incubation medium is not, however, the exclusive precursor of $\alpha$-glycerophosphate. Without knowledge of the specific radioactivity of $\alpha$-glycerophosphate, the measurement of glucose incorporation from the medium into tissue glycerides can only serve as an approximate and minimal measure of esterification. 2) There is fatty acid synthesis from acetate. The enzymatic processes by which this is achieved in a variety of animal tissues have recently been reviewed by Martin and Vagelos (13). The fate of these newly synthesized fatty acids is largely determined by the relative rates of oxidation, esterification, and lipolysis. Since there are several possible sources of tissue acetate, measurement of the rate of incorporation of acetate from the medium into adipose glycerides is only a minimal estimate of de novo fatty acid synthesis. 3) FFA are taken up from the incubation medium and incorporated into glycerides (6). The rate of incorporation of labeled FFA from the medium into adipose glycerides is dependent upon activity of the esterification process and also upon the rates of lipolysis and FFA release. When the specific activity of FFA in the medium is used for calculating uptake as was done in this study, the true rate of FFA esterification will be grossly underestimated. 4) FFA are released from the adipose tissue into the incubation medium (1). The rate at which this occurs reflects the net effect of the rates of lipolysis and esterification. As a rule, the rates of lipolysis and esterification are in balance (11), and only under unusual circumstances, e.g., when adipose tissue is incubated in the presence of growth hormone, is lipolysis stimulated independently of esterification (14). Thus, FFA release is a poor quantitative index of lipolysis. However, by determining glycerol production as described by Vaughan (11), it is possible to make a selective evaluation of the activity of the lipolytic process.

The present studies indicate that starvation and semistarvation in man lead to a number of changes in the metabolism of adipose tissue. To the extent that the four parameters measured can be 
used as indexes of separate phenomena within the cell, negative caloric balance apparently effects a reduction in FFA uptake, virtual cessation of $d e$ novo fatty acid synthesis, and only moderate depression of esterification, but a great increase in FFA release. This suggests that the enhanced FFA release was a result of greater lipolysis; however, until glycerol measurements can be sufficiently refined to be applicable to these small tissue fragments, a strict quantitative estimate of the degree of lipolysis cannot be obtained. The consistent depression of acetate incorporation into adipose lipid during starvation might be due in part to an increase in the intracellular pool of acetyl-CoA during starvation. Unfortunately, all of these measurements are limited by lack of knowledge about the radioactivity of tissue precursor pools.

On rapid termination of the fasting state with intravenous glucose and insulin, there was no immediate recovery of de novo fatty acid synthesis or of triglyceride synthesis as measured by glucose incorporation into glycerides. However, the very small increase in both FFA uptake and the proportion of these acids esterified indicates a small but measurable repair of one of the functional defects induced by starvation. The most striking effect, however, was a sudden and profound decrease in the rate of FFA release. This was so great as to suggest that the lipolysis was selectively decreased with very little change in the rate of esterification.

In the rat, starvation and refeeding lead to more marked converse changes in the rates of FFA esterification and release, suggesting closer interdependence of these two parameters than can be shown in man. Thus, for example, starvation causes more pronounced inhibition of esterification (3), and refeeding effects a more rapid recovery of esterification and fatty acid synthesis $(5,6)$ than was observed in these studies. Moreover, the addition of glucose and insulin to the media in incubations of adipose tissue from the starved rat causes inhibition of FFA release and significant acceleration of esterification and fatty acid synthesis (1-3).

The addition of insulin to media containing glucose in incubations of adipose tissue from humans in negative caloric balance failed to ef- fect any metabolic changes. Similar difficulties have been encountered with adipose tissue from individuals in the isocaloric state when an insulin effect has been looked for in vitro, and it is unclear whether this apparent resistance of human tissues to the presence of insulin can be attributed solely to the method used in obtaining the fat (8). These observations seem to indicate that human adipose tissue differs from that of the rat in its response to starvation, refeeding, and possibly to the presence of insulin in the incubation medium. It will be important, therefore, to determine whether the differences observed between rat and man reflect fundamental differences in metabolism or inadequate methods for measuring the metabolic parameters of adipose tissue.

The striking parallelism observed between the plasma levels and release rates of FFA from adipose tissue strongly supports the concept that the plasma FFA are derived from and controlled by the metabolic activities of the adipose organ. This concept is further supported by studies in which the plasma FFA concentrations in man are sharply altered by the administration of epinephrine or of carbohydrate and insulin, and in starvation, hyperthyroidism, and uncontrolled diabetes $(10,15-18)$; under similar circumstances, appropriate alterations in FFA release can be demonstrated in rat adipose tissue $(1,19-22)$.

All of these observations indicate that adipose tissue plays a dominant role in the control of plasma FFA levels in man. It is of interest, therefore, that gas-liquid chromatographic analysis of plasma FFA shows a pattern that is so different from that of adipose tissue (23). This would suggest that, although the plasma FFA are derived from adipose tissue, they are not an unselected sample of adipose glyceride fatty acids. Thus, the possibility should be kept in mind that the plasma FFA are derived from some smaller pool of fatty acids within the fat cell or are secondarily modified in composition by passage through other tissues.

The small number of subjects studied precluded a systematic comparison of the effects of caloric restriction on the metabolism of adipose tissue between the obese and nonobese. However, adipose tissue from grossly obese individuals showed no obvious difference in response to starvation from 
that observed in persons of average body build. Moreover, it has not been possible to demonstrate an abnormality in adipose tissue metabolism when obese subjects were studied in the isocaloric state (8). This information, together with the observation that the cellular contents of nitrogen and fat are not very different in extreme ranges of body weight (8), suggests that the accumulation of excess adipose tissue is not associated with any fundamental change in the metabolic activity of the individual fat cell. On the other hand, for reasons that are obscure, the presence of obesity is associated with abnormally high levels of plasma insulin both before and after a glucose load (24, 25). Thus, an obese individual cannot be regarded as metabolically normal. For this reason, the data reported in the present study on the in vivo effects of insulin on the metabolism of adipose tissue may not apply to individuals of normal body build.

\section{Summary}

Several metabolic functions of adipose tissue were measured serially in obese and nonobese individuals during the course of caloric restriction and refeeding.

Caloric restriction was shown to depress fatty acid uptake and esterification, virtually abolish fatty acid synthesis, and enhance FFA release from adipose tissue. Refeeding was associated with relatively slow restoration of fatty acid synthesis and esterification toward normal levels.

Intravenous administration of glucose and insulin to starved obese individuals effected prompt inhibition of FFA release, slight restoration of fatty acid uptake, and esterification but no change in fatty acid synthesis.

During starvation and its rapid termination by glucose and insulin, variations in the rate of FFA release from adipose tissue were accompanied by parallel changes in the concentrations of plasma FFA.

\section{Acknowledgments}

The capable technical assistance of Mrs. Carolyn Hunsicker is gratefully acknowledged, as is the help of Dr. E. H. Ahrens, Jr., in the preparation of the manuscript.

\section{References}

1. Gordon, R. S., Jr., and A. Cherkes. Production of unesterified fatty acids from isolated rat adipose tissue incubated in vitro. Proc. Soc. exp. Biol. (N. Y.) 1958, 97, 150.

2. Perry, W. F. Acetate utilization by liver and adipose tissue of rats fasted in the cold. Canad. J. Biochem. 1958, 36, 237.

3. Cahill, G. F., B. Leboeuf, and A. E. Renold. Factors concerned with the regulation of fatty acid metabolism by adipose tissue. Amer. J. clin. Nutr. 1960, 8, 733 .

4. Hausberger, F. X., and S. W. Milstein. Dietary effects on lipogenesis in adipose tissue. J. biol. Chem. 1955, 214, 483.

5. Miller, J. P., J. A. D. Cooper, and S. Freeman. Lipogenesis in adipose tissue, dietary effects. Proc. Soc. exp. Biol. (N. Y.) 1957, 95, 817.

6. Shapiro, B., I. Chowers, and G. Rose. Fatty acid uptake and esterification in adipose tissue. Biochim. biophys. Acta (Amst.) 1957, 23, 115.

7. Rose, G., and B. Shapiro. The synthesis of fatty acids and glycogen by adipose tissue in vitro. Biochim. biophys. Acta (Amst.) 1955, 18, 504.

8. Hirsch, J., and R. B. Goldrick. Serial studies on the metabolism of human adipose tissue. I. Lipogenesis and free fatty acid uptake and release in small aspirated samples of subcutaneous fat. J. clin. Invest. 1964, 43, 1776.

9. Ahrens, E. H., Jr., V. P. Dole, and D. H. Blankenhorn. The use of orally fed liquid formulas in metabolic studies. Amer. J. clin. Nutr. 1954, 2, 336.

10. Dole, V. P. A relation between non-esterified fatty acids in plasma and the metabolism of glucose. J. clin. Invest. 1956, 35, 150.

11. Vaughan, M. The production and release of glycerol by adipose tissue incubated in vitro. J. biol. Chem. 1962, 237, 3354.

12. Steinberg, D., M. Vaughan, and S. Margolis. Studies of triglyceride biosynthesis in homogenates of adipose tissue. J. biol. Chem. 1961, 236, 1631.

13. Martin, D. B., and P. R. Vagelos. The mechanism of tricarboxylic acid cycle regulation of fatty acid synthesis. J. biol. Chem. 1962, 237, 1787.

14. Vaughan, M., and D. Steinberg. Effect of hormones on lipolysis and esterification of free fatty acids during incubation of adipose tissue in vitro. $\mathrm{J}$. Lipid Res. 1963, 4, 193.

15. Gordon, R. S., Jr., and A. Cherkes. Unesterified fatty acid in human blood plasma. J. clin. Invest. 1956, 35, 206.

16. Gordon, R. S., Jr. Unesterified fatty acid in human blood plasma. II. The transport function of unesterified fatty acid. J. clin. Invest. 1957, 36, 810.

17. Rich, C., E. L. Bierman, and I. L. Schwartz. Plasma nonesterified fatty acids in hyperthyroid states. T. clin. Invest. 1959, 38, 275. 
18. Bierman, E. L., V. P. Dole, and T. N. Roberts. An abnormality of nonesterified fatty acid metabolism in diabetes mellitus. Diabetes 1957, 6, 475.

19. Cahill, G. F., Jr., B. Leboeuf, and R. B. Flinn. Studies on rat adipose tissue in vitro. VI. Effect of epinephrine on glucose metabolism. J. biol. Chem. 1960, 235, 1246.

20. Hagen, J. H. Effect of insulin on the metabolism of adipose tissue from hyperthyroid rats. J. biol. Chem. 1960, 235, 2600.

21. Debons, A. F., and I. L. Schwartz. Dependence of the lipolytic action of epinephrine in vitro upon thyroid hormone. J. Lipid Res. 1961, 2, 86.
22. Wertheimer, E., M. Hamosh, and E. Shafrir. Factors affecting fat mobilization from adipose tissue. Amer. J. clin. Nutr. 1960, 8, 705.

23. Hirsch, J., J. W. Farquhar, E. H. Ahrens, Jr., M. L. Peterson, and W. Stoffel. Studies of adipose tissue in man. A microtechnic for sampling and analysis. Amer. J. clin. Nutr. 1960, 8, 499.

24. Karam, J. H., G. M. Grodsky, and P. H. Forsham. Excessive insulin response to glucose in obese subjects as measured by immunochemical assay. Diabetes 1963, 12, 197.

25. Phear, D. N. The normal and diabetic patterns of insulin response to glucose. Lancet 1962, 2, 955. 